\title{
Increasing seismic hazard and risk awareness in Central Sulawesi, Indonesia: Seismometers in Schools Pilot Programme
}

\author{
Richard Woods ${ }^{1, *}$, Michele Daly ${ }^{1}$, Agung Setianto ${ }^{2}$, Esti Anantasari ${ }^{2}$, and Richard Johnson ${ }^{1}$ \\ ${ }^{1}$ GNS Science, 1 Fairway Drive, Lower Hutt 5040, New Zealand. \\ ${ }^{2}$ Universitas Gadjah Mada, Bulaksumur, Caturtunggal, Kec. Depok, Kabupaten Sleman, Daerah \\ Istimewa Yogyakarta 55281, Indonesia
}

\begin{abstract}
Central Sulawesi is bisected by the Palu-Koru Fault and other nearby faults. Despite numerous earthquakes, there is very little awareness of these fault structures and their potential to cause damage. Through the Strengthened Indonesian Resilience: Reducing Risks from Disasters (StIRRRD) programme, the local Badan Penanggulangan Bencana Daerah (BPBD) in both Donggala and Palu identified a concern about the lack of community knowledge of local seismic hazards and risks. They wish to see an increased awareness of the Palu-Koro Fault using a programme that builds on existing hazard and preparedness programmes in schools. To help achieve this, StIRRRD launched Indonesia's first pilot Seismometers in Schools (SIS) programme, in partnership with the Badan Meteorologi, Klimatologi, dan Geofisika (BMKG) and Lembaga Ilmu Pengetahuan Indonesia (LIPI), in Central Sulawesi in March 2018. Seismometers in Schools is an education initiative already present in Australia, New Zealand and the United States which involves installing seismometers in schools as a tool to increase awareness of seismic hazards and risks. Information from the seismometers can be analysed by mathematics, physics or geography students to assess earthquakes recorded locally or from around the world. Seismometers have been installed in four schools, SMA Negeri Model Terpadu Madani and MAN 1 in Palu City, SMA N 1 Banawa in Donggala and SMA N 1 Bahadopi in Morowali with a more sophisticated three component device installed at the University of Tadulako, Palu. To compliment the installation, teaching resource packs were gifted and training workshops held with teachers to assist them with better integrating local seismic hazard and risk projects into their curriculums.
\end{abstract}

\section{Seismic Hazard Awareness in Central Sulawesi}

Central Sulawesi is bisected by the Palu-Koru Fault, a large transform fault, as well as numerous other fault structures (Walpersdorf et al., 1998). Despite the numerous

\footnotetext{
${ }^{*}$ Corresponding author: r.woods@gns.cri.nz
} 
earthquakes and active landscape, there is very little awareness of the fault structures and their potential to cause damage to villages and citied in the future.

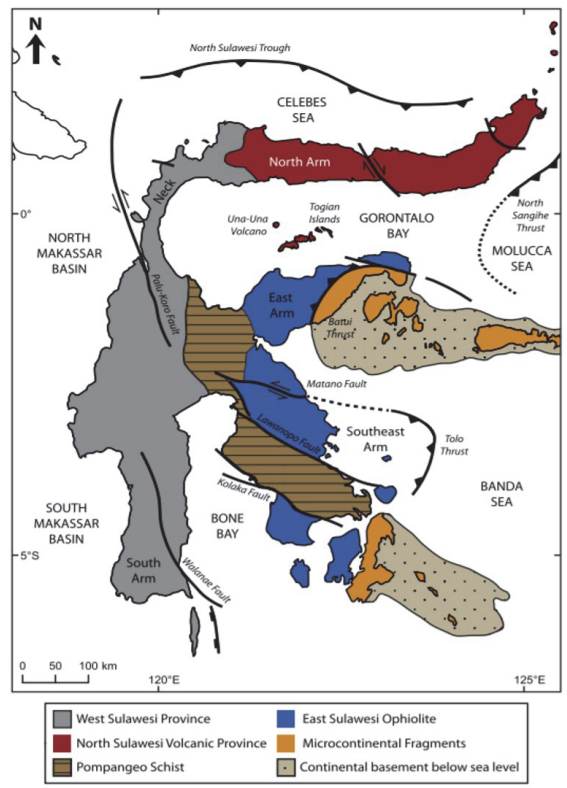

Fig. 1. Geology of Sulawesi showing the location of the Palu-Koro Fault. Reproduced from White et al 2014.

Activities, associated with the StIRRRD programme in Palu, Donggala and Morowali, identified concern about the lack of community knowledge of local seismic hazards and related risks. Donggala and Palu BPBD have implemented hazard awareness and preparedness programmes in their schools and both districts are interested in a community project which supports these programmes. In response, StIRRRD has established the Seismometers in Schools pilot programme as an exemplar for local disaster risk reduction initiatives that can be undertaken in Sulawesi.

\section{Seismometers in Schools Programmes}

There have been a number of 'Seismometer in Schools' (SIS) programmes launched internationally as a platform to increase youth interest in earthquake science (Balfour et al, 2014; Bullen, 1998; Courboulex, 2012). The Australian Seismometers in Schools Network (AuSIS), being one of the most comprehensive programmes, installed seismometers in over 40 Australian secondary schools to engage students in monitoring the earth through seismology as well as contributing to earthquake detection and research for Australia (Balfour et al, 2014).

The Central Sulawesi SIS programme, implemented in March 2018, uses a similar methodology to AuSIS through the installation of seismometers supported by a range of school education and outreach activities. The seismometers are earthquake detection devices which record all local earthquakes, including those which may not be felt by people, and large distant earthquakes. The earthquakes are displayed on a monitor as a seismic trace (Figure 2) which students can interpret and compare to traces on other devices either locally or globally through the online global Raspberry Shake seismometer network (www.raspberryshake.net). The data collected can also be fed into a national seismograph network and/or be collected by the local university, Universitas Tadulako (UNTAD), and 
the national seismic agency Badan Meterologi, Klimatologi, dan Geofisika (BKMG) for future education and research purposes.

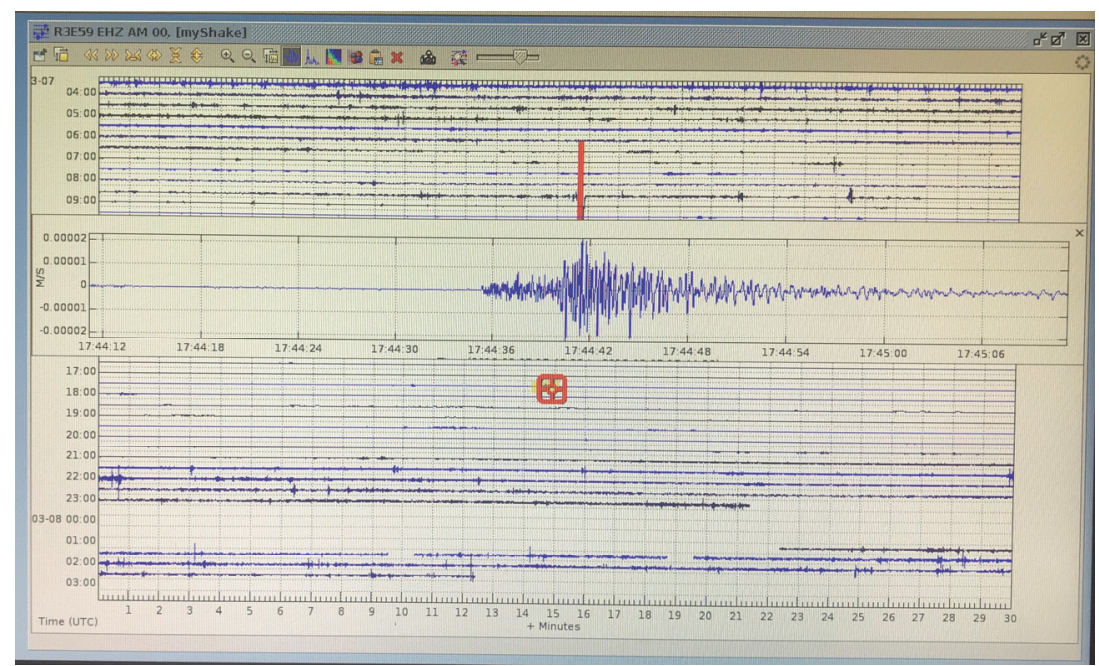

Fig. 2. Example of the seismic trace produced by the Raspberry Shake seismometer.

\section{Central Sulawesi SIS Pilot Project Implementation}

During the week 5 March 2018, StIRRRD team members were based in Palu, Central Sulawesi to launch Indonesia's first Seismometers in Schools (SIS) programme. The project installed four seismometers in public schools and a more sophisticated three component seismometer at the University of Tadulako, Palu. The pilot programme schools are SMA Negeri Model Terpadu Madani and MAN 1 in Palu City, SMA N 1 Banawa in Donggala and SMA N 1 Bahadopi in Morowali (Figure 3).

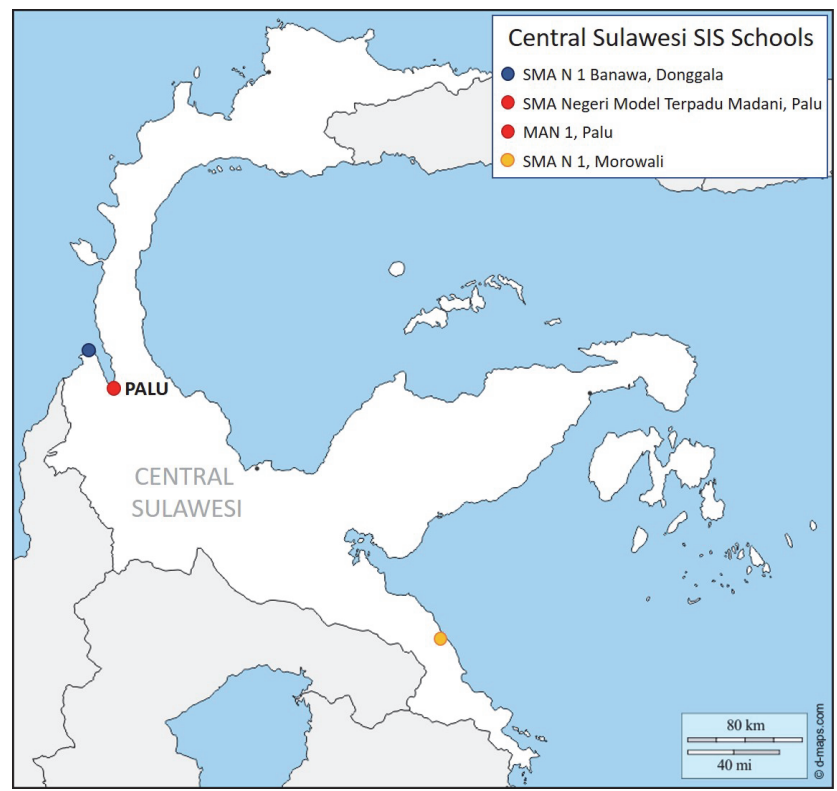

Fig. 3 Map showing the location of participating SIS pilot schools. 
On Monday 5 March, team members visited all schools in Palu and Donggala, to begin installing seismometers and meeting with key staff from each school. The team were warmly welcomed to all schools with teachers expressing gratitude and excitement that their schools were chosen to be a part of the project. During the week, installation of the seismometers was completed and training workshops for teachers and students held to increase their knowledge of earthquake and tsunami risks in their local area.

On Tuesday 6 March, the team visited SMA Negeri Model Terpadu Madani (Figure 4) where a welcome ceremony was followed by an overview of local seismic hazards and capacity building a group of selected students and teachers. Training was largely delivered by experts from the Universistas Gadjah Mada (UGM), GNS Science and a representative from the Indonesia's Institute of Sciences (LIPI). Teachers and students were highly engaged during the session which was followed by a visit to the recently installed seismometer. That afternoon, targeted training sessions for the teachers were held, supported by local agencies, to provide them with resources and knowledge regarding the seismometers and local seismic risks. This included a demonstration of how the seismometer works by a technician from GNS Science followed by a discussion on ideas for future student projects, to be aligned with teaching plans, using the seismometer.
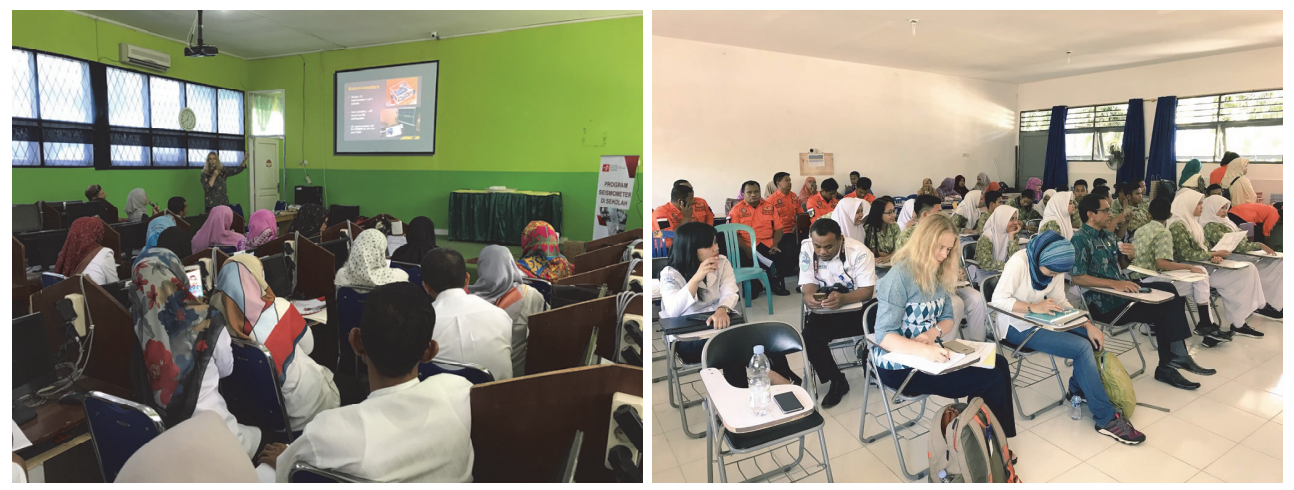

Fig. 4 Seismic hazard and risk training delivered to teachers and students during the SIS pilot deployment.

The same programme was delivered to MAN 1 in Palu City and SMA N 1 Banawa in Donggala on 7 and 8 March respectively. A highlight was returning to Donggala on Thursday and discovering that their seismometer had already detected its first earthquake the night before. The last seismometer was installed in SMA N 1 Bahadopi, Morowali in May by UGM experts and technicians assisted by the local BMKG office.

On Friday 9 March, the team completed the installation of a more sophisticated threecomponent seismometer at the Universitas of Tadulako (UNTAD). This device will support future research projects on the seismicity of the area and provide more data for the local Palu-Koro Fault seismic network managed by BMKG.

\section{SIS Pilot Programme Support}

Importantly, the project has been supported by a range of Indonesian agencies willing to assist the schools with technical support and further training. Their commitment was 
recognised in a Memorandum of Understanding (MoU) signing ceremony on 5 March (Figure 5). The agencies signing the MoU include:

- Palu's local university - Universitas of Tadulako (UNTAD)

- The provincial office of the national seismic monitoring agency - Kantor Stasiun Geofisika Palu (BMKG)

- The local emergency management offices - BPBD Kota Palu \& BPBD Kabupaten Donggala

- The provincial office of the national education office - Dinas Pendidikan Provinsi Sulawesi Tengah

- The provincial office of the national Ministry of Religion - Kakanwil Kemenag Provinsi Sulawesi Tengah

All agencies agreed to help with technical assistance, further capacity building for teachers, help with assessing earthquake traces and providing ideas on how students might develop future projects. On 7 July, an additional teacher training workshop was held in Palu with contributions from each of these agencies as a part of this continued support.
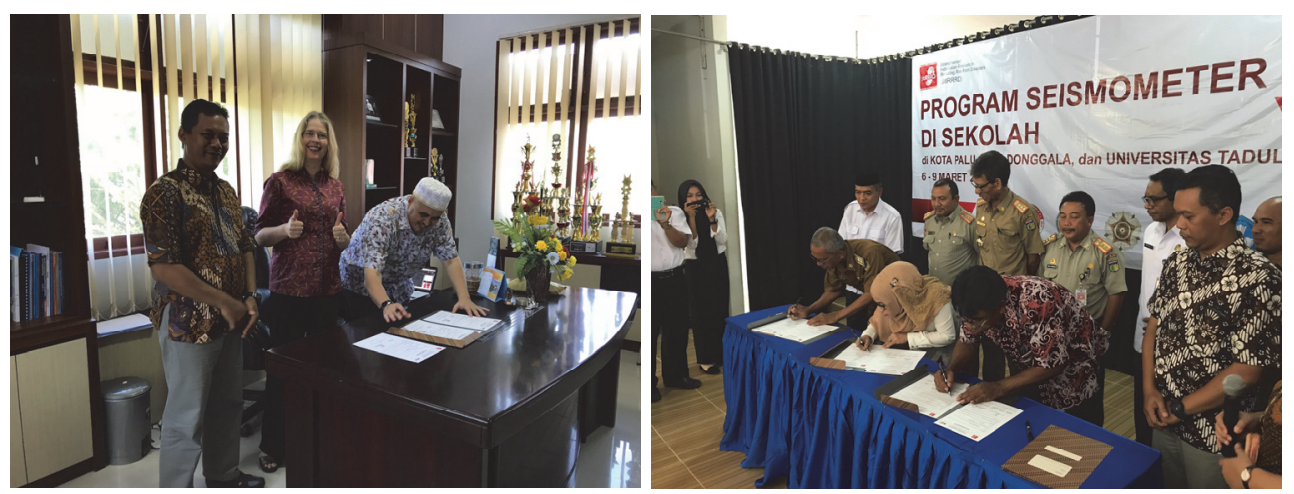

Fig. $5 \mathrm{MoU}$ signing ceremony (right) with support agencies and UNTAD (left).

Overall, there was a lot of excitement about the new seismometers and opportunities to increase the capacity of teachers and knowledge of the high seismic risk present in Palu, Donggala and Morowali. This interest was reflected by high engagement across social media platforms during the SIS installation in March with the national emergency management ministry (BNPB), the New Zealand embassy in Jakarta and UNTAD regularly liking and retweeting tweets via Twitter. Globally, organisations such as the Raspberry Shake Seismometer network (based in Panama), Australian SIS project, the IRIS earthquake programme (based in Washington) and the British Geological Survey seismology project were also very engaged by commenting, liking and retweeting posts.

\section{Pilot Evaluation}

The pilot evaluation is scheduled to coincide with the International Conference on Urban Disaster Resilience (ICUDR), hosted by UNTAD, to be held in November 2018. The evaluation will assess whether the programme has had significant uptake, whether seismic related projects have been integrated into teaching plans and whether knowledge of the local seismic and tsunami hazards has improved. Students who are undertaking projects will also be subject to an inter-school competition with the winner being announced during the ICUDR conference. 


\section{References}

Balfour, N.J., Salmon, M., Sambridge, M. (2014) The Australian Seismometers in Schools Network: Education, Outreach, Research, and Monitoring, Seismological Research Letters 85 (5) pp. 1063-1068.

Bullen, S. (1998) Seismology in Schools, Astronomy \& Geophysics 39 (4) pp. 4.25-4.26

Corboulex, F., Berenbuer, J.L., Tocheport, A., Bouin, M.P., Calais, E., Esnault, Y., Larroque, C., Nolet, G., Virieux, J. (2012) Sismos a l'Ecole : A Worldwide Network of Real-Time Seismometers in Schools, Seismological Research Letters 83 (5) pp. 870-873.

Walpersdorf, A., Vigny, C., Subarya, C., Manurung, P. (1998) Monitoring of the Palu-Koro Fault (Sulawesi) by GPS, Geophysical Research Letters 25 (13)

White, L.T., Hall, R., Armstrong, R.A. (2014) The age of undeformed dacite intrusions within the Kolaka Fault Zone, SE Sulawesi, Indonesia, Journal of Asian Earth Sciences 94 pp. 105-112.

\section{Online References}

$\underline{\text { www.raspberryshake.net }}$ 